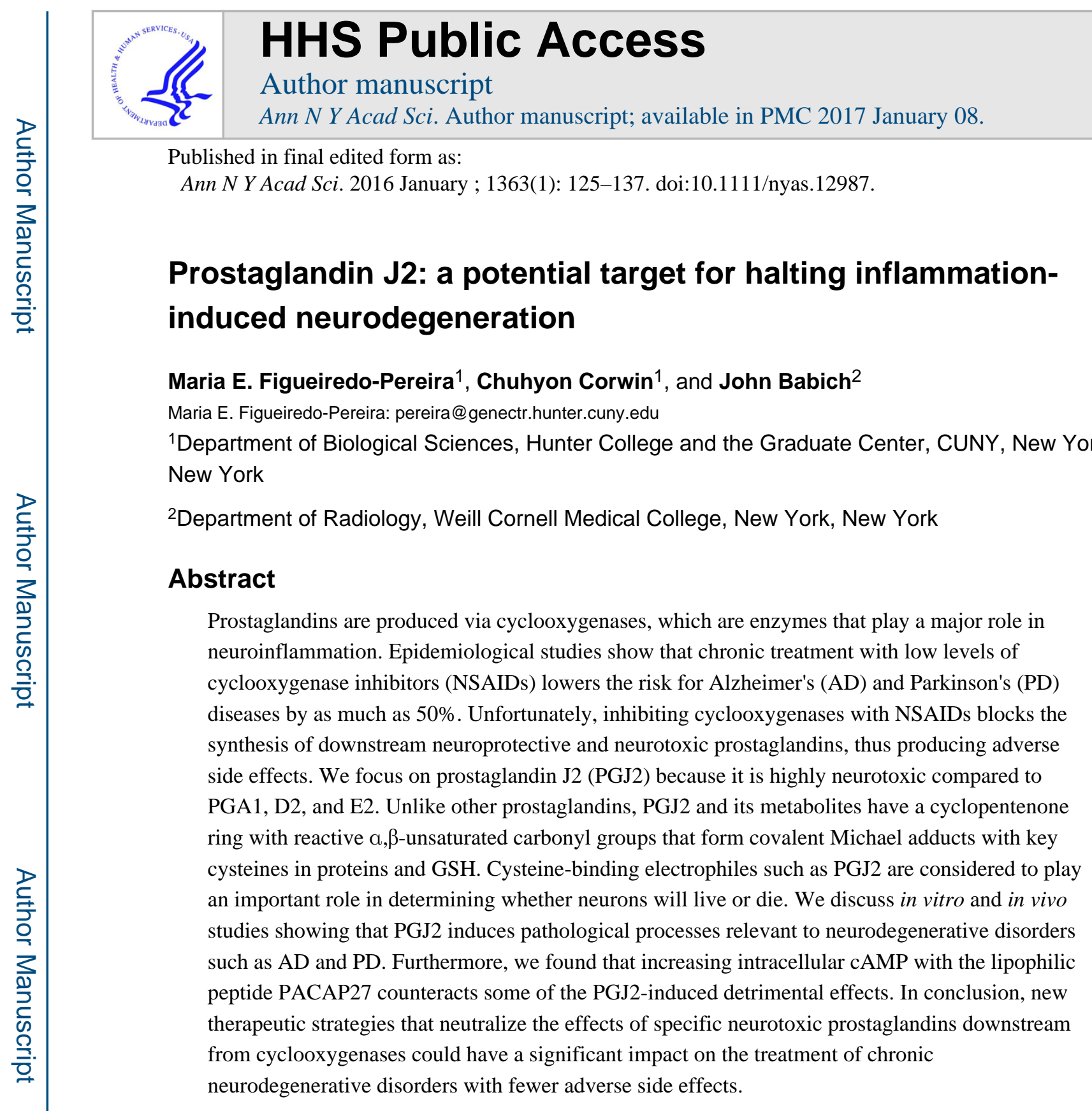

\title{
Keywords
}

prostaglandin J2; NSAID; Michael adducts; cyclooxygenases; chronic inflammation; Alzheimer's and Parkinson's diseases

One of the critical factors that contributes to neurodegeneration and its progression in neurodegenerative disorders such as Alzheimer's (AD) and Parkinson's diseases (PD) is neuroinflammation. ${ }^{1-3}$ An important aspect of neuroinflammation is the cyclooxygenase pathway that includes the constitutive cyclooxygenase I (COX-1) and the inducible cyclooxygenase II (COX-2). ${ }^{4}$ Cyclooxygenases generate a range of prostaglandins, the

\footnotetext{
Address for correspondence: Maria E. Figueiredo-Pereira, 695 Park Avenue, Room 827N, New York, NY 10065.

Conflicts of interest: The authors declare no conflicts of interest.

Portions of this article are derived from Ref. 27.
} 
biosynthesis of which is blocked by nonsteroidal anti-inflammatory drugs (NSAIDs). Based on epidemiological studies, NSAIDs are the only currently available drugs known to decrease the risk and/or delay the onset of these disorders and other neurodegenerative conditions. ${ }^{5}$ However, the causal relationship between the prostaglandin products of cyclooxygenases and neurodegeneration has been poorly investigated to date.

\section{Neurodegeneration and Neuroinflammation}

$\mathrm{AD}$ and $\mathrm{PD}$ are chronic neurodegenerative disorders that develop over time and worsen with aging. Neuroinflammation is a common hallmark of these disorders and is considered to be one of their drivers and not just a consequence of the ongoing neurodegeneration. ${ }^{6-8}$ Postmortem, genetic, and epidemiological studies confirm that neuroinflammation plays a critical role in the neuropathology and progression of AD and PD. First, activated microglia, peripheral macrophages, and $\mathrm{T}$ lymphocytes are detected postmortem in the affected areas of $\mathrm{AD}$ and $\mathrm{PD}$ patients, in concert with increased levels of COX-2 and other proinflammatory mediators. ${ }^{1,3,9-12}$ Second, a spectrum of AD- and PD-associated genes were shown to be linked to neuroinflammation. For example, mutations in the amyloid precursor protein (APP) linked to early onset $\mathrm{AD}$ affect the generation and/or aggregation of the amyloid $\beta$ (A $\beta$ ) peptide. ${ }^{8}$ Soluble, oligomeric, and fibril forms of $\mathrm{A} \beta$ bind to and activate microglia. ${ }^{2}$ PD-associated mutations in the genes encoding LRRK2, Parkin, and a-synuclein are also related to inflammation. ${ }^{13}$ Moreover, genome-wide association studies (GWAS) reported that variations in loci encoding immune-related genes are genetic risk factors for $\mathrm{AD}$, such as triggering receptor expressed on myeloid cells 2 (TREM2) ${ }^{14,15}$ and CD33 $3^{16,17}$, as well as for PD, such as human leukocyte antigen (HLA), bone marrow stromal cell antigen 1 (BST1), and TREM2. ${ }^{13,18}$ Lastly, epidemiological studies show an inverse relation between the use of some NSAIDs such as aspirin, ibuprofen, and naproxen, and the risk of developing $\mathrm{AD}$ and $\mathrm{PD},{ }^{19,20}$ with the risk reduction being as much as $50 \% .{ }^{5}$ Although there are conflicting results, ${ }^{1,5}$ the link is most evident for the use of ibuprofen. ${ }^{21,22}$ Clinical studies with NSAIDs have not showed a similar trend. ${ }^{1,23}$ It has been postulated that the chronic use of NSAIDs is beneficial only in the early stages of AD or PD and that it may be too late to target inflammation with these drugs once clinical symptoms are apparent. ${ }^{5,24} \mathrm{~A}$ better understanding of the shared and diverse mechanism of action of these drugs, including cyclooxygenase inhibition and decreased prostaglandin production, is required to more effectively modulate the neurotoxic outcomes of neuroinflammation with fewer side effects. ${ }^{1}$

Neuroinflammation is a localized response of the CNS to brain injury induced by infection and toxic metabolites, as well as conditions such as traumatic brain injury and stroke.

Neuroinflammation is also a nonspecific response, as it always results in microglia activation independent of the initiating stimulus. Acute inflammation is resolved immediately after the injured site is healed. However, neuroinflammation is widely regarded as chronic inflammation of the CNS that extends beyond the original site and spreads to healthy areas.

Neuroinflammation involves sustained activation of glial cells (microglia and astrocytes) and other immune cells recruited into the brain by crossing a compromised blood-brain 
barrier, thus perpetuating the immune response. Upon activation, both microglia and astrocytes undergo morphological changes. In addition, activated microglia release a spectrum of inflammatory mediators that include prostaglandins, cytokines, chemokines, reactive free radicals, and proteases. Some of these mediators are neuroprotective while others are neurotoxic, supporting the notion that neuroinflammation is a double-edged sword playing both detrimental and beneficial roles depending on the circumstances. ${ }^{25,26}$

\section{Prostaglandins in AD and PD}

Prostaglandins (PGs) are a family of 20-carbon unsaturated fatty acids produced via the cyclooxygenase pathway in response to extrinsic and intrinsic stimuli (reviewed in Ref. 27). The initial step in prostaglandin synthesis involves the hydrolysis of membrane sn-2 glycerophospholipids (phosphatidylcholine, phosphatidylethanolamine, and phosphatidylinositol) by the cytoplasmic phospholipase A2 (PLA2 group IVA) to release arachidonic acid. ${ }^{28-30}$ PLA2 is activated by increased calcium levels and phosphorylation. Once activated, PLA2 translocates from the cytoplasm to intracellular membranes, including the endoplasmic reticulum and nuclear envelope, where it has access to arachidonic acidcontaining phospholipid substrates. ${ }^{31}$ Cyclooxygenases, which are bifunctional enzymes inserted into the ER and nuclear membranes, will then catalyze the cyclooxygenation of arachidonic acid to PGG2, followed by hydroperoxidation of PGG2 to PGH2. ${ }^{32-34} \mathrm{PGH} 2$ diffuses from the ER lumen through its membrane to the cytoplasm to be converted to more polar prostanoids, via prostaglandin-specific synthases localized on the cytoplasmic face of the ER. ${ }^{35}$ The coupling of PGH2 synthesis with the respective downstream prostaglandin synthases that produce different types of prostaglandins is intricately orchestrated in a tissue- and/or cell-specific manner. ${ }^{36}$

Cyclooxygenases COX-1 and COX-2 function as homodimers. ${ }^{29}$ Although the brain expresses COX-1 and COX-2 under normal physiological conditions, it is clear that cyclooxygenases are implicated in neurodegeneration. ${ }^{11,37} \mathrm{COX}-1$ is constitutively expressed and is generally viewed as being the homeostatic isoform, but studies suggest that it is actively involved in some forms of brain injury. ${ }^{38,39}$ The expression and activity of COX-2 are largely responsive to adverse stimuli and physiologic imbalances. ${ }^{40} \mathrm{COX}-2$ upregulation following CNS injury is not restricted to neurons, since COX-2 induction is also apparent in glia. ${ }^{41}$ Although many studies support the notion that COX-1 and COX-2 are involved in neurodegeneration, the contribution of their prostaglandin products to the neurodegenerative process remains poorly defined. ${ }^{38}$ NSAIDs' therapeutic effectiveness could be compromised, as these drugs block the generation of all prostaglandin products of cyclooxygenases, including those that are neuroprotective and those that are neurotoxic.

Upon neuronal injury, activated microglia produce large quantities of prostaglandins, such as PGD2 and PGE2, ${ }^{42}$ as well as PGJ2, ${ }^{43}$ which act as potent local regulators of physiologic and pathologic pathways linked to neuroinflammation. For example, PGE2 induces neuroprotection or neurotoxicity depending on the cell type and the receptor that it activates. Binding of PGE2 to its EP4 receptor in neurons is highly protective in a mouse model of cerebral ischemia. ${ }^{44}$ However, preventing PGE2 binding to its EP2 receptor in microglia 
restores beneficial microglial function and prevents the progression of AD pathology in animal models. ${ }^{45}$

PGD2 is the most abundant prostaglandin in the brain ${ }^{4,46-48}$ and the one that becomes the most elevated under pathological conditions. ${ }^{49}$ PGD2 levels are also significantly increased in the frontal cortex of $\mathrm{AD}$ patients compared to age-matched controls. ${ }^{50} \mathrm{PGD} 2$ is produced by two distinct types of prostaglandin D2 synthases (PGDS): (1) the lipocalin enzyme (LPGDS) that is present in the brain and is regulated by estradiol, ${ }^{51}$ and (2) the hematopoietic enzyme (H-PGDS) that is mostly active in the immune system and mast cells. ${ }^{52}$ In addition, PGD2 binds to the G protein-coupled receptors (GPCRs) DP1 and DP2. ${ }^{52}$ In AD patients and in Tg2576 mice, a well-established AD model, the levels of H-PGDS and DP1 were found to be selectively upregulated in microglia and astrocytes within senile plaques. ${ }^{53}$ These results indicate that PGD2 acts as a mediator of plaque-associated inflammation in the AD brain. ${ }^{53}$ Similarly, L-PGDS, which is one of the most abundant CSF proteins produced in the brain, was detected in amyloid plaques in both $\mathrm{AD}$ patients and $\mathrm{Tg} 2576$ mice. $^{54}$ Secreted L-PGDS in the CSF has a dual function: it increases CSF-PGD2 levels ${ }^{55}$ and also acts as a lipophilic-ligand carrier. ${ }^{56} \mathrm{~L}-\mathrm{PGDS}$ was found to bind $\mathrm{A} \beta$ monomers and prevent $A \beta$ aggregation, suggesting that L-PGDS is a major $A \beta$ chaperone, and disruption of this function could be related to the onset and progression of AD. ${ }^{54}$

Investigations on the role of PGD2 in PD are more recent and therefore less extensive. ${ }^{57}$ Nevertheless, there are a few studies supporting the role of PGD2 in PD. For example, significant changes in L-PGDS isoforms were detected in the CSF of at least 20 idiopathic PD patients compared to 100 controls. ${ }^{58}$ These alterations reflected up/downregulation of LPGDS isoforms likely to represent pathology at the cellular level, to affect prostaglandin production, and to correlate with disease symptoms. ${ }^{58}$ It was speculated that these altered isoforms could be candidate diagnostic biomarkers of PD, and they may have predictive value..$^{58}$

\section{Why investigate the role of PGJ2?}

PGD2 is highly unstable (estimated brain half-life of $1.1 \mathrm{~min}$ ) and readily undergoes spontaneous dehydration to generate the biologically active cyclopentenone $\mathrm{J} 2$ prostaglandins, which include PGJ2, $\Delta 12-\mathrm{PGJ} 2$ and 15-deoxy- $\Delta 12,14-\mathrm{PGJ} 2$ (15d-PGJ2) (Fig. 1) ${ }^{59}$ The neurotoxic effects of PGD2 were shown to be mediated by the bioactive J2 prostaglandins. ${ }^{59}$ Formation of cyclopentenone eicosanoids in the brain, such as PGJ2, is a novel pathogenic mechanism that potentially contributes to many neurodegenerative conditions, including AD and PD. ${ }^{60}$ Upon stroke and TBI, the in vivo concentration of free PGJ2 in the rodent brain increases from almost undetectable to an average of $100 \mathrm{nM}^{61,62}$ Since PGJ2 binds covalently to proteins, local cellular and intracellular concentrations of PGJ2 are potentially even higher. ${ }^{59}$ Stroke and TBI increase the long-term risk for $\mathrm{AD}^{63}$ and $\mathrm{PD},{ }^{64 ; 65}$ thus strongly supporting the idea that PGJ2 contributes to the pathogenesis of these disorders. PGJ2 was also shown to accumulate in the spinal cord of sporadic amyotrophic lateral sclerosis (ALS) patients. ${ }^{66}$ 
Our studies focus on PGJ2 because we established in neuronal cultures that PGJ2 was by far the most neurotoxic of the four prostaglandins that we tested, including PGA1, D2, E2, and J2, with PGE2 being the least neurotoxic of the four. ${ }^{67}$ PGJ2 is a highly toxic prostaglandin that impairs the ubiquitin/proteasome pathway (UPP) by targeting (a) the $26 \mathrm{~S}$ proteasome, perturbing its assembly and oxidatively modifying the S6ATPase (Rpt3) subunit, and (2) deubiquitinating enzymes such as UCH-L1; thus, PGJ2 induces the accumulation/aggregation of ubiquitinated $(\mathrm{Ub})$ proteins. ${ }^{61,62,67-72}$ PGJ2 also disrupts cytoskeletal integrity, ${ }^{68,73,74}$ induces oxidative stress ${ }^{75}$ and neuronal apoptosis, ${ }^{66}$ and inhibits mitochondrial complex 1 activity. ${ }^{76}$ Thus, PGJ2 induces many of the pathological processes involved in AD and PD. ${ }^{27}$

\section{Receptor-dependent PGJ2 signaling}

J2 prostaglandins bind to DP1 and DP2, which are GPCRs for PGD2. ${ }^{52}$ DP1 and DP2, like other GPCR prostaglandin receptors, are present not only at the plasma membrane ${ }^{4}$ but also at the nuclear membrane, thus providing for intracrine (intracellular) signaling. ${ }^{77} \mathrm{DP} 1$ activation is coupled to the G protein Gs, resulting in increased cAMP levels, whereas DP2 activation is coupled to $\mathrm{G}_{i}$, thus decreasing cAMP levels and increasing intracellular calcium. ${ }^{78}$ Moreover, DP2 activation potentiates neuronal injury in hippocampal neuronal cultures and organotypic slices, while DP1 activation is neuroprotective. ${ }^{11,49} \mathrm{~J} 2$ prostaglandins have a higher affinity for DP2 (by as much as 100-fold) than for DP1, and bind to DP2 with an affinity similar to PGD2 (i.e., in the nanomolar range). ${ }^{79,80}$

Although controversial, ${ }^{4}$ the J2 prostaglandins $15 \mathrm{~d}-\mathrm{PGJ} 2$ and $\Delta 12-\mathrm{PGJ} 2$ are considered to be endogenous ligands for the nuclear peroxisomal proliferator activator receptor (PPAR $\gamma$ ), to which they bind with high affinity. ${ }^{81,82}$ PPAR $\gamma$ activation in the nucleus plays a major role in the regulation of adipogenesis, glucose homeostasis, cellular differentiation, apoptosis, and inflammation. ${ }^{83}$ PPAR $\gamma$ agonists, such as the $\mathrm{J} 2$ prostaglandins, promote neuroprotection in models of stroke, $\mathrm{AD}, \mathrm{HD}, \mathrm{PD}$, multiple sclerosis, and spinal cord injury, via anti-inflammatory- or antioxidant-dependent mechanisms. ${ }^{84-86}$

\section{Posttranslational covalent modification of proteins by PGJ2}

Unlike most prostaglandins, PGJ2 and its metabolites 15d-PGJ2 and $\Delta 12-\mathrm{PGJ} 2$ have a cyclopentenone ring with a, $\beta$-unsaturated carbonyl groups (Fig. 2, red star). These carbonyl groups are highly reactive with free cysteine thiols in glutathione and proteins, forming covalent Michael adducts ${ }^{87,88}$ (Fig. 2). This highly conserved redox reaction involving cysteine thiols and PGJ2 in the brain represents a novel pathologic change and could play a critical role in neurodegeneration in $\mathrm{AD}$ and $\mathrm{PD} .{ }^{89}$

Electrophile binding (S-alkylation, Fig. 2) by endogenous compounds such as PGJ2 is currently regarded to play an important role in determining whether neurons will live or die. ${ }^{88}$ This posttranslational protein modification seems to be highly selective, as only a specific set of cysteine residues are vulnerable to covalent modification, independent of protein thiol content. ${ }^{89,90}$ Of the several hundred cellular proteins with potentially reactive thiols, only $\sim 10 \%$ form covalent adducts with $\mathrm{J} 2$ prostaglandins and are considered members of the electrophile-responsive proteome ${ }^{91,92}$ Proteomic approaches identified 358 
proteins in human aortic endothelial cells that are covalently modified by $15 \mathrm{~d}-\mathrm{PGJ} 2 .{ }^{93} \mathrm{~J} 2$ prostaglandins covalently bind to specific sites within the plasma membrane, as well as within the nuclear and cytosolic subcellular fractions. ${ }^{94}$ At least 11 plasma membrane proteins were identified as binding biotinylated $15 \mathrm{~d}-\mathrm{PGJ} 2$, and they were distributed into three functional groups: glycolytic enzymes, molecular chaperones, and cytoskeletal proteins. ${ }^{94}$ Furthermore, J2 prostaglandin binding alters protein catalysis, binding, structural function, and transport. ${ }^{93,95}$

\section{Contrasting effects of $\mathrm{J} 2$ prostaglandins}

The role of $\mathbf{J} 2$ prostaglandins in inflammation is complex..$^{96,97}$ Under certain conditions, they exert anti-inflammatory effects by inhibiting the production of proinflammatory mediators, such as iNOS, TNFa, and IL1 $\beta$; suppressing microglia and astrocyte activation; and inducing apoptosis..$^{98-100}$ In other circumstances, J2 prostaglandins are proinflammatory agents. They stimulate the production of proinflammatory mediators such as IL8, activate MAPK, ${ }^{101,102}$ and activate microglia as well as astrocytes. ${ }^{103,104}$. Furthermore, 15d-PGJ2 seems to play a role in the regulation of human autoimmune diseases and to inhibit inflammation in models of arthritis, ischemia-reperfusion injury, inflammatory bowel disease, lupus nephritis, and AD. ${ }^{105}$

J2 prostaglandins also display both protective and destructive effects. Their biological activities include antiviral and antitumoral effects, modulation of the heat shock response, induction of oxidative stress and apoptosis, ${ }^{106}$ upregulation of the death receptor 5 (DR5), sensitization to TRAIL-induced cytotoxicity, and caspase 8 activation. ${ }^{66,107-109}$ Although their antiproliferative and proapoptotic effects are most frequently described, J2 prostaglandins also induce the proliferation of different forms of cancer cells when used at nanomolar to low micromolar concentrations. ${ }^{110}$

The effects of $\mathrm{J} 2$ prostaglandins most likely depend on their intracellular targets and downstream pathways, which can be dose and cell type dependent. ${ }^{111} \mathrm{~J} 2$ prostaglandins may exert some of their anti- or proinflammatory as well as anti- or prosurvival effects through PPAR $\gamma$-dependent mechanisms. However, these prostaglandins also exert their actions through PPAR $\gamma$-independent pathways, including activation of the MAPK and JNK pathways, ${ }^{112,113}$ stabilization of the transcription factor Nrf2 via its interaction with Keap1,14-116 and inhibition of the NF-kB pathway. ${ }^{117,118}$. This may account for the different effects of 15d-PGJ2 compared to other PPAR $\gamma$ ligands, such as pioglitazone, which do not replicate all of the effects attributed to J2 prostaglandins. ${ }^{55}$ Identifying the mechanism by which $\mathrm{J} 2$ prostaglandins exert their neurotoxic effects could lead to new strategies to prevent and/or delay neurodegeneration linked to inflammation.

\section{Potential role of PGJ2 in the transition from acute to chronic inflammation}

The mechanisms underlying the transition from acute to chronic inflammation are poorly understood. It has been postulated that, besides being mediators of acute inflammation, prostaglandins also function in the transition and maintenance of chronic inflammation, thus inducing long-lasting effects. ${ }^{119}$ Prostaglandins accomplish this by amplifying cytokine signaling, upregulating COX-2, inducing chemokines, and recruiting inflammatory cells 
such as macrophages. ${ }^{119} \mathrm{We}$ and others demonstrated that PGJ2 induces COX-2 upregulation in cancer cells ${ }^{120 ; 121}$ and neuronal cells. ${ }^{113}$ Thus, PGJ2 may facilitate the transition from acute to chronic inflammation (Fig. 3) via a positive feedback loop that involves COX-2 upregulation. ${ }^{113,119}$ A slow, steady stream-like release of J2 prostaglandins as a result of chronic neuroinflammation could be cumulative, leading overtime to accumulation of covalent PGJ2-protein adducts until they reach a toxic threshold. The covalent protein modification in the brain by highly reactive electrophiles such as J2 prostaglandins represents a novel pathologic posttranslational change ${ }^{122}$ that may play a critical role in progressive neurodegeneration.

Prostaglandins are largely produced by activated microglia and reactive astrocytes (less by neurons) during neuroinflammation. PGJ2 also induces microglia and astrocyte activation. ${ }^{103,104}$ Characterizing the self-perpetuating cycle of inflammatory processes involving PGJ2 in the brain that potentially drives the slow progression of neurodegeneration will contribute to preventing/arresting neurodegenerative disorders, such as $\mathrm{AD}$ and $\mathrm{PD}$, that are associated with the cyclooxygenase pathway.

\section{Lipopolysaccharide (LPS)-mediated models of neurodegeneration}

LPS-mediated models of neuroinflammation are often used to address the relationship between neuroinflammation and the pathogenesis of AD and PD. ${ }^{123}$ LPS is a lipoglycan component of the Gram-negative bacterial outer wall that binds to CD14 on microglia membranes and elicits a strong immune reaction in animals. Single systemic administration of LPS to adult rats induced hippocampal-dependent selective impairment in context-object discrimination, but not spatial memory, mimicking, in part, AD cognitive deficits. ${ }^{124}$ In mice, a single LPS systemic administration caused progressive dopaminergic neuronal loss. ${ }^{125}$ Unfortunately, as microglia are present in a variety of brain regions, activation of microglia and the subsequent proinflammatory response induced by systemically administered LPS are not specific and include other regions of the brain relevant to AD or PD. To overcome this drawback, LPS is also administered intracranially into the fourth ventricle or hippocampus for $\mathrm{AD}$-like models ${ }^{126}$ or the $\mathrm{SN}$, striatum, or globus pallidus for PD-like models. ${ }^{127}$ Both AD- and PD-like models exhibit microglia activation. Intracellular $\mathrm{A} \beta$ aggregates ${ }^{128}$ and apoptotic neuronal death ${ }^{129}$ were detected in the AD-like models. ${ }^{126}$ PD-like models show dopaminergic neuron loss with no damage to GABAergic or serotoninergic neurons, enhanced a-synuclein nitration, increased level of proinflammatory cytokines (IL-1 $\beta$, TNF- $a$, IL-6, and NO), and motor deficits. ${ }^{127}$ A significant finding is that the LPS-induced pathological changes were more severe in middle-aged (16-month-old) rats than in young (3-month-old) rats, supporting the view that aging is a critical risk factor in the development of PD. ${ }^{130}$

One of the shortfalls of the LPS models of AD and PD is that, when injected intracranially, the LPS effect is very acute, causing, for example, nigral DA neuronal loss within 24 hours that persists at the same level over 30 days, therefore not mimicking the progressive nature of PD pathology. ${ }^{131}$ In addition, these LPS models of AD or PD address the central role of inflammation in these disorders, but they do not distinguish which of the factors produced by activated microglia and astrocytes induce neurodegeneration. This is a very important 
issue since some products of inflammation are neuroprotective and others neurotoxic. The mechanisms by which neurotoxic prostaglandins target neurons remain critical missing links in the proof of a pathogenic role for the cyclooxygenase pathway in AD and PD.

\section{Justification for PGJ2 rodent models}

As far as we know, there are no models of $\mathrm{AD}$ or PD that include administering prostaglandin products of cyclooxygenases to mimic the pathology of these disorders. This is a critical gap, not only because COX-2 is highly induced in AD and PD brains, but also because NSAIDs, which inhibit prostaglandin biosynthesis, are the only currently established drugs that potentially decrease the risks and/or delay the onset of these disorders. Unfortunately, these drugs have serious side effects that include bleeding and ulcers. Therefore, there is an urgent need to develop more potent anti-inflammatory drugs with fewer undesirable side effects. Investigating the effects of neurotoxic prostaglandins will contribute to the development of drugs that fulfill this need.

Our recent studies focus on establishing PGJ2-induced rodent models of PD. Our previously established PGJ2 mouse model of PD addresses the potential of a specific prostaglandin to induce PD pathology or how to protect from it. ${ }^{103,104} \mathrm{We}$ determined that nigral/striatal microinfusion of PGJ2 into adult (12-week-old) FVB male mice led to (a) a dose-dependent reduction in the number of dopaminergic neurons in the substantia nigra pars compacta (SNpc) with little damage to dopaminergic neurons in the ventral tegmental area (VTA) and GABAergic interneurons in the SN pars reticulata (SNpr); (2) activated microglia and astrocytes; (3) detection of neuronal Lewy-like bodies with ubiquitinated proteins; and (4) impaired gait and balance mimicking PD motor deficits. Since PGJ2 upregulates the expression and activity of COX-2, ${ }^{113}$ PGJ2 also has potential to initiate a series of deleterious cascades leading to self-sustained progressive neurodegeneration. Thus, PGJ2based PD animal models can serve an important role in developing and evaluating possible neuroprotective or neurorestorative therapeutics for PD patients.

Our current studies (unpublished) are investigating a PGJ2-induced rat model of PD. Rat models offer many advantages over mouse models for human disease. ${ }^{132}$ Compared to the mouse, rat physiology is easier to monitor and closer to the human condition, and rats are more intelligent and capable of learning a broader variety of tasks. ${ }^{132}$ Rats are also larger than mice and thus better suited for the use of $\mu \mathrm{PET}$ in preclinical research and drug development, due to the requirement of high spatial resolution to visualize the structures of interest and to maintain quantitative accuracy.

According to our preliminary results, PGJ2 has a similar toxic effect on mice and rats. This is not the case for all drug-based PD models. For unknown reasons, some environmental toxin-based models are species specific. For example, rats are resistant to MPTP, and the MPTP sensitivities of different strains of mice differ widely. ${ }^{133}$ On the other hand, mice and other species are resistant to rotenone under the conditions tested for the rotenone rat model. ${ }^{133}$ The PGJ2 mouse and rat models will potentially show equivalent pathology. 


\section{Therapeutic interventions for AD and PD with a focus on PGJ2}

$\mathrm{J} 2$ prostaglandins bind to the $\mathrm{G}_{i}$-coupled DP2 receptor, resulting in a decrease in basal cAMP levels (discussed above). We confirmed this by showing that PGJ2 lowers neuronal cAMP. ${ }^{109}$ On the basis of these findings, we investigated whether agents that restore and/or elevate intracellular cAMP will overcome the toxic effects of PGJ2. We focused on PACAP (pituitary adenylate cyclase-activating polypeptide), which is a lipophilic peptide that signals via activation of the $\mathrm{G}_{s}$ protein-coupled receptor PAC1R (pituitary adenylate cyclase 1 receptor). ${ }^{134}$ PAC1R is expressed in the cerebral cortex, hippocampus, SNpc, ventral tegmental area, and other brain areas. ${ }^{135,136}$ Nanomolar concentrations of the two forms of PACAP, PACAP38 and the truncated form PACAP27, activate adenylate cyclase and elevate intracellular cAMP. ${ }^{134}$ The mechanisms by which PACAP mediates neuroprotection are reviewed in Ref. 137. We and others demonstrated that PACAP treatment of neuronal cultures overcomes the decrease in cAMP levels induced by PGJ2, 109;138 as well as neuronal death and proteasome deficits. ${ }^{109}$ PACAP treatment also provides neuroprotection in several in vivo models of $\mathrm{AD}$ and $\mathrm{PD}$ by exerting antiapoptotic, anti-inflammatory, and antioxidant effects, ${ }^{139}$ thus supporting the neuroprotective potential of PACAP administration.

We evaluated the neuroprotective effects of PACAP27 in the PGJ2-induced mouse model of PD. ${ }^{103}$ PACAP27 suppressed PGJ2-induced dopaminergic neuronal loss and motor deficits but not the sustained microglia activation. ${ }^{103}$ Our results with PACAP27 suggest that persistent microglia activation is likely to play a key role in disease progression, extending beyond the time of injury. It is clear that the PD pathology exhibited by the PGJ2-induced mouse model involves integrated signaling across neurons and microglia. There is a need to optimize candidate anti-inflammatory therapies designed to target the integrated signaling across neurons and microglia to fully benefit patients with AD or PD.

Another approach to target the adverse effects of PGJ2 is the development of pathologically activated therapeutics (PATs). ${ }^{140}$ The principle of these types of drugs is that they only become active at the site of injury, thus decreasing potential severe side effects and improving drug tolerance by the treated patients. Some of these PATs are compounds, such as carnosic acid and some other types of hydroquinones, which only become electrophilic at the site of tissue injury undergoing oxidative stress. ${ }^{141,142}$ Once electrophilic, these PATs activate the Keap1/Nrf2/ARE (antioxidant-response element) transcription pathway, via $S$ alkylation of specific cysteines in Keap1. This results in Nrf2 stabilization and translocation to the nucleus to induce the synthesis of endogenous antioxidant phase 2 enzymes. ${ }^{88}$ These neuroprotective PATs are weaker electrophiles than others that are neurotoxic, such as PGJ2. ${ }^{140}$ Stronger electrophiles, such as PGJ2, $S$-alkylate glutathione (GSH) cysteines. depleting the intracellular reducing conditions, leading to ROS accumulation and mitochondrial dysfunction. ${ }^{143-145}$ The contrasting neuroprotective or neurotoxic effects of $S$-alkylating electrophiles depends in part on which cysteines they target. A precise identification of the cysteine targets of electrophiles like $\mathrm{J} 2$ prostaglandins is important to understand and develop improved therapeutics to combat their neurodegenerative effects. ${ }^{141}$ 


\section{Conclusions}

J2 prostaglandins are endogenous products of the cyclooxygenase pathway that exhibit proand anti-inflammatory effects through receptor-mediated and receptor-independent signaling. J2 prostaglandins induce many of the pathological changes involved in AD and PD, including (1) inhibition of the proteasome and the ubiquitin hydrolase UCH-L1 and accumulation/aggregation of ubiquitinated proteins; (2) disruption of cytoskeleton integrity; (3) oxidative stress, mitochondrial complex 1 inhibition, and neuronal apoptosis; and (4) COX-2 upregulation as well as microglia and astrocyte activation, which may initiate a positive feedback loop and lead to progressive long-term effects. Drugs that are currently available to inhibit the cyclooxygenase pathway, such as NSAIDs, are effective for preventing/halting inflammation, but unfortunately produce severe side effects. Therapeutic strategies, such as the ones we discussed, that target neurotoxic factors downstream of cyclooxygenases, including $\mathrm{J} 2$ prostaglandins, offer great promise as a new approach that maintains the homeostatic balance offered by the cyclooxygenase pathway. This new therapeutic approach is relevant to $\mathrm{AD}, \mathrm{PD}$, and other neurodegenerative disorders in which the cyclooxygenase pathway of inflammation plays a critical role in mediating neurodegeneration.

\section{References}

1. Hirsch EC, Vyas S, Hunot S. Neuroinflammation in Parkinson's disease. Parkinsonism Relat Disord. 2012; 18 (Suppl 1):S210-S212. [PubMed: 22166438]

2. Heneka MT, Carson MJ, El KJ, Landreth GE, Brosseron F, Feinstein DL, Jacobs AH, Wyss-Coray T, Vitorica J, Ransohoff RM, Herrup K, Frautschy SA, Finsen B, Brown GC, Verkhratsky A, Yamanaka K, Koistinaho J, Latz E, Halle A, Petzold GC, Town T, Morgan D, Shinohara ML, Perry VH, Holmes C, Bazan NG, Brooks DJ, Hunot S, Joseph B, Deigendesch N, Garaschuk O, Boddeke E, Dinarello CA, Breitner JC, Cole GM, Golenbock DT, Kummer MP. Neuroinflammation in Alzheimer's disease. Lancet Neurol. 2015; 14:388-405. [PubMed: 25792098]

3. Wyss-Coray T, Rogers J. Inflammation in Alzheimer disease-a brief review of the basic science and clinical literature. Cold Spring Harb Perspect Med. 2012; 2:a006346. [PubMed: 22315714]

4. Ricciotti E, FitzGerald GA. Prostaglandins and inflammation. Arterioscler Thromb Vasc Biol. 2011; 31:986-1000. [PubMed: 21508345]

5. Czirr E, Wyss-Coray T. The immunology of neurodegeneration. J Clin Invest. 2012; 122:1156-63. [PubMed: 22466657]

6. Sankowski R, Mader S, Valdes-Ferrer SI. Systemic inflammation and the brain: novel roles of genetic, molecular, and environmental cues as drivers of neurodegeneration. Front Cell Neurosci. 2015; 9:28. [PubMed: 25698933]

7. Rocha NP, de Miranda AS, Teixeira AL. Insights into Neuroinflammation in Parkinson's Disease: From Biomarkers to Anti-Inflammatory Based Therapies. Biomed Res Int. 2015; 2015:628192. [PubMed: 26295044]

8. Heppner FL, Ransohoff RM, Becher B. Immune attack: the role of inflammation in Alzheimer disease. Nat Rev Neurosci. 2015; 16:358-72. [PubMed: 25991443]

9. Yoshiyama Y, Higuchi M, Zhang B, Huang SM, Iwata N, Saido TC, Maeda J, Suhara T, Trojanowski JQ, Lee VM. Synapse loss and microglial activation precede tangles in a P301S tauopathy mouse model. Neuron. 2007; 53:337-51. [PubMed: 17270732]

10. Zagol-Ikapitte I, Masterson TS, Amarnath V, Montine TJ, Andreasson KI, Boutaud O, Oates JA. Prostaglandin H(2)-derived adducts of proteins correlate with Alzheimer's disease severity. Journal of Neurochemistry. 2005; 94:1140-5. [PubMed: 15992375] 
11. Liang X, Wu L, Wang Q, Hand T, Bilak M, McCullough L, Andreasson K. Function of COX-2 and prostaglandins in neurological disease. Journal of Molecular Neuroscience. 2007; 33:94-9. [PubMed: 17901552]

12. Gomez-Nicola D, Boche D. Post-mortem analysis of neuroinflammatory changes in human Alzheimer's disease. Alzheimers Res Ther. 2015; 7:42. [PubMed: 25904988]

13. Dzamko N, Geczy CL, Halliday GM. Inflammation is genetically implicated in Parkinson's disease. Neuroscience. 2015; 302:89-102. [PubMed: 25450953]

14. Guerreiro R, Wojtas A, Bras J, Carrasquillo M, Rogaeva E, Majounie E, Cruchaga C, Sassi C, Kauwe JS, Younkin S, Hazrati L, Collinge J, Pocock J, Lashley T, Williams J, Lambert JC, Amouyel P, Goate A, Rademakers R, Morgan K, Powell J, St George-Hyslop P, Singleton A, Hardy J. TREM2 variants in Alzheimer's disease. N Engl J Med. 2013; 368:117-27. [PubMed: 23150934]

15. Jonsson T, Stefansson H, Steinberg S, Jonsdottir I, Jonsson PV, Snaedal J, Bjornsson S, Huttenlocher J, Levey AI, Lah JJ, Rujescu D, Hampel H, Giegling I, Andreassen OA, Engedal K, Ulstein I, Djurovic S, Ibrahim-Verbaas C, Hofman A, Ikram MA, van Duijn CM, Thorsteinsdottir U, Kong A, Stefansson K. Variant of TREM2 associated with the risk of Alzheimer's disease. N Engl J Med. 2013; 368:107-16. [PubMed: 23150908]

16. Bradshaw EM, Chibnik LB, Keenan BT, Ottoboni L, Raj T, Tang A, Rosenkrantz LL, Imboywa S, Lee M, Von KA, Morris MC, Evans DA, Johnson K, Sperling RA, Schneider JA, Bennett DA, De Jager PL. CD33 Alzheimer's disease locus: altered monocyte function and amyloid biology. Nat Neurosci. 2013; 16:848-50. [PubMed: 23708142]

17. Griciuc A, Serrano-Pozo A, Parrado AR, Lesinski AN, Asselin CN, Mullin K, Hooli B, Choi SH, Hyman BT, Tanzi RE. Alzheimer's disease risk gene CD33 inhibits microglial uptake of amyloid beta. Neuron. 2013; 78:631-43. [PubMed: 23623698]

18. Rayaprolu S, Mullen B, Baker M, Lynch T, Finger E, Seeley WW, Hatanpaa KJ, Lomen-Hoerth C, Kertesz A, Bigio EH, Lippa C, Josephs KA, Knopman DS, White CL, Caselli R, Mackenzie IR, Miller BL, Boczarska-Jedynak M, Opala G, Krygowska-Wajs A, Barcikowska M, Younkin SG, Petersen RC, Ertekin-Taner N, Uitti RJ, Meschia JF, Boylan KB, Boeve BF, Graff-Radford NR, Wszolek ZK, Dickson DW, Rademakers R, Ross OA. TREM2 in neurodegeneration: evidence for association of the $\mathrm{p}$. R47H variant with frontotemporal dementia and Parkinson's disease Mol Neurodegener. 2013; 8:19. [PubMed: 23800361]

19. Klegeris A, McGeer EG, McGeer PL. Therapeutic approaches to inflammation in neurodegenerative disease. Current Opinion In Neurology. 2007; 20:351-7. [PubMed: 17495632]

20. Vlad SC, Miller DR, Kowall NW, Felson DT. Protective effects of NSAIDs on the development of Alzheimer disease. Neurology. 2008; 70:1672-7. [PubMed: 18458226]

21. Gao X, Chen H, Schwarzschild MA, Ascherio A. Use of ibuprofen and risk of Parkinson disease. Neurology. 2011; 76:863-9. [PubMed: 21368281]

22. Rainsford, KD. Ibuprofen in prevention of neurodegenerative diseases, Ibuprofen: discovery, developmeny and therapeutics. Hoboken, Rainsford KD., editor. John Wiley \& sons; 2015. p. 547-70.

23. Rainsford KD. Anti-inflammatory drugs in the 21st century. Sub-cellular Biochemistry. 2007; 42:3-27. [PubMed: 17612044]

24. Imbimbo BP, Solfrizzi V, Panza F. Are NSAIDs useful to treat Alzheimer's disease or mild cognitive impairment? Front Aging Neurosci. 2010; 2 Article 19.

25. Gao HM, Hong JS. Why neurodegenerative diseases are progressive: uncontrolled inflammation drives disease progression. Trends Immunol. 2008; 29:357-65. [PubMed: 18599350]

26. Kaushik DK, Basu A. A friend in need may not be a friend indeed: role of microglia in neurodegenerative diseases. CNS Neurol Disord Drug Targets. 2013; 12:726-40. [PubMed: 24070095]

27. Figueiredo-Pereira ME, Rockwell P, Schmidt-Glenewinkel T, Serrano P. Neuroinflammation and J2 prostaglandins: linking impairment of the ubiquitin-proteasome pathway and mitochondria to neurodegeneration. Frontiers in Molecular Neuroscience. 2015; 7:104. [PubMed: 25628533]

28. Tassoni D, Kaur G, Weisinger RS, Sinclair AJ. The role of eicosanoids in the brain. Asia Pac J Clin Nutr. 2008; 17 (Suppl 1):220-8. [PubMed: 18296342] 
29. Smyth EM, Grosser T, Wang M, Yu Y, FitzGerald GA. Prostanoids in health and disease. Journal of Lipid Research. 2009; 50 (Suppl):S423-S428. [PubMed: 19095631]

30. Astudillo AM, Balgoma D, Balboa MA, Balsinde J. Dynamics of arachidonic acid mobilization by inflammatory cells. Biochim Biophys Acta. 2012; 1821:249-56. [PubMed: 22155285]

31. Shimizu M, Nakamura H, Hirabayashi T, Suganami A, Tamura Y, Murayama T. Ser515 phosphorylation-independent regulation of cytosolic phospholipase A2alpha (cPLA2alpha) by calmodulin-dependent protein kinase: possible interaction with catalytic domain A of cPLA2alpha. Cell Signal. 2008; 20:815-24. [PubMed: 18280113]

32. Kulkarni SK, Jain NK, Singh A. Cyclooxygenase isoenzymes and newer therapeutic potential for selective COX-2 inhibitors. Methods and Findings In Experimental and Clinical Pharmacology. 2000; 22:291-8. [PubMed: 11031730]

33. Smith WL, DeWitt DL, Garavito RM. Cyclooxygenases: structural, cellular, and molecular biology. Annual Review of Biochemistry. 2000; 69:145-82.

34. Simmons DL, Botting RM, Hla T. Cyclooxygenase isozymes: the biology of prostaglandin synthesis and inhibition. Pharmacological Reviews. 2004; 56:387-437. [PubMed: 15317910]

35. Schuster VL. Prostaglandin transport. Prostaglandins Other Lipid Mediat. 2002; 68-69:633-47. [PubMed: 12432949]

36. Funk CD. Prostaglandins and leukotrienes: advances in eicosanoid biology. Science. 2001; 294:1871-5. [PubMed: 11729303]

37. Bartels AL, Leenders KL. Cyclooxygenase and neuroinflammation in Parkinson's disease neurodegeneration. Current Neuropharmacology. 2010; 8:62-8. [PubMed: 20808546]

38. Aid S, Bosetti F. Targeting cyclooxygenases-1 and -2 in neuroinflammation: Therapeutic implications. Biochimie. 2011; 93:46-51. [PubMed: 20868723]

39. Choi SH, Aid S, Bosetti F. The distinct roles of cyclooxygenase-1 and -2 in neuroinflammation: implications for translational research. Trends in Pharmacological Sciences. 2009; 30:174-81. [PubMed: 19269697]

40. Yamagata K, Andreasson KI, Kaufmann WE, Barnes CA, Worley PF. Expression of a mitogeninducible cyclooxygenase in brain neurons: regulation by synaptic activity and glucocorticoids. Neuron. 1993; 11:371-86. [PubMed: 8352945]

41. Consilvio C, Vincent AM, Feldman EL. Neuroinflammation, COX-2, and ALS--a dual role? Experimental Neurology. 2004; 187:1-10. [PubMed: 15081582]

42. Liu B, Gao HM, Hong JS. Parkinson's disease and exposure to infectious agents and pesticides and the occurrence of brain injuries: role of neuroinflammation. Environmental Health Perspectives. 2003; 111:1065-73. [PubMed: 12826478]

43. Bernardo A, Ajmone-Cat MA, Levi G, Minghetti L. 15-deoxy-delta12,14-prostaglandin J2 regulates the functional state and the survival of microglial cells through multiple molecular mechanisms. Journal of Neurochemistry. 2003; 87:742-51. [PubMed: 14535956]

44. Liang X, Lin L, Woodling NS, Wang Q, Anacker C, Pan T, Merchant M, Andreasson K. Signaling via the prostaglandin $\mathrm{E}(2)$ receptor $\mathrm{EP} 4$ exerts neuronal and vascular protection in a mouse model of cerebral ischemia. J Clin Invest. 2011; 121:4362-71. [PubMed: 21965326]

45. Johansson JU, Woodling NS, Wang Q, Panchal M, Liang X, Trueba-Saiz A, Brown HD, Mhatre SD, Loui T, Andreasson KI. Prostaglandin signaling suppresses beneficial microglial function in Alzheimer's disease models. J Clin Invest. 2015; 125:350-64. [PubMed: 25485684]

46. Shaik JS, Miller TM, Graham SH, Manole MD, Poloyac SM. Rapid and simultaneous quantitation of prostanoids by UPLC-MS/MS in rat brain. J Chromatogr B Analyt Technol Biomed Life Sci. 2014; 945-946:207-16.

47. Hertting G, Seregi A. Formation and function of eicosanoids in the central nervous system. Annals of the New York Academy of Sciences. 1989; 559:84-99. [PubMed: 2672946]

48. Ogorochi T, Narumiya S, Mizuno N, Yamashita K, Miyazaki H, Hayaishi O. Regional distribution of prostaglandins D2, E2, and F2 alpha and related enzymes in postmortem human brain. Journal of Neurochemistry. 1984; 43:71-82. [PubMed: 6427411]

49. Liang X, Wu L, Hand T, Andreasson K. Prostaglandin D2 mediates neuronal protection via the DP1 receptor. J Neurochem. 2005; 92:477-86. [PubMed: 15659218] 
50. Iwamoto N, Kobayashi K, Kosaka K. The formation of prostaglandins in the postmortem cerebral cortex of Alzheimer-type dementia patients. Journal of Neurology. 1989; 236:80-4. [PubMed: 2709057]

51. Mong JA, Devidze N, Frail DE, O'Connor LT, Samuel M, Choleris E, Ogawa S, Pfaff DW. Estradiol differentially regulates lipocalin-type prostaglandin D synthase transcript levels in the rodent brain: Evidence from high-density oligonucleotide arrays and in situ hybridization. Methods in Molecular Biology. 2003; 100:318-23.

52. Urade Y, Eguchi N. Lipocalin-type and hematopoietic prostaglandin D synthases as a novel example of functional convergence. Prostaglandins Other Lipid Mediat. 2002; 68-69:375-82. [PubMed: 12432930]

53. Mohri I, Kadoyama K, Kanekiyo T, Sato Y, Kagitani-Shimono K, Saito Y, Suzuki K, Kudo T, Takeda M, Urade Y, Murayama S, Taniike M. Hematopoietic prostaglandin D synthase and DP1 receptor are selectively upregulated in microglia and astrocytes within senile plaques from human patients and in a mouse model of Alzheimer disease. Journal of Neuropathology and Experimental Neurology. 2007; 66:469-80. [PubMed: 17549007]

54. Kanekiyo T, Ban T, Aritake K, Huang ZL, Qu WM, Okazaki I, Mohri I, Murayama S, Ozono K, Taniike M, Goto Y, Urade Y. Lipocalin-type prostaglandin D synthase/beta-trace is a major amyloid beta-chaperone in human cerebrospinal fluid. Methods in Molecular Biology. 2007; 104:6412-7.

55. Scher JU, Pillinger MH. 15d-PGJ2: the anti-inflammatory prostaglandin? Clin Immunol. 2005; 114:100-9. [PubMed: 15639643]

56. Urade Y, Hayaishi O. Prostaglandin D synthase: structure and function. Vitamins and Hormones. 2000; 58:89-120. [PubMed: 10668396]

57. Rogers J, Mastroeni D, Leonard B, Joyce J, Grover A. Neuroinflammation in Alzheimer's disease and Parkinson's disease: are microglia pathogenic in either disorder? International Review of Neurobiology. 2007; 82:235-46. [PubMed: 17678964]

58. Harrington MG, Fonteh AN, Biringer RG, AF RH, Cowan RP. Prostaglandin D synthase isoforms from cerebrospinal fluid vary with brain pathology. Disease Markers. 2006; 22:73-81. [PubMed: 16410653]

59. Liu H, Li W, Rose ME, Pascoe JL, Miller TM, Ahmad M, Poloyac SM, Hickey RW, Graham SH. Prostaglandin D toxicity in primary neurons is mediated through its bioactive cyclopentenone metabolites. Neurotoxicology. 2013; 39C:35-44. [PubMed: 23973622]

60. Musiek ES, Milne GL, McLaughlin B, Morrow JD. Cyclopentenone eicosanoids as mediators of neurodegeneration: a pathogenic mechanism of oxidative stress-mediated and cyclooxygenasemediated neurotoxicity. Brain Pathology. 2005; 15:149-58. [PubMed: 15912888]

61. Liu H, Li W, Ahmad M, Miller TM, Rose ME, Poloyac SM, Uechi G, Balasubramani M, Hickey RW, Graham SH. Modification of ubiquitin-C-terminal hydrolase-L1 by cyclopentenone prostaglandins exacerbates hypoxic injury. Neurobiol Dis. 2011; 41:318-28. [PubMed: 20933087]

62. Liu H, Li W, Ahmad M, Rose ME, Miller TM, Yu M, Chen J, Pascoe JL, Poloyac SM, Hickey RW, Graham SH. Increased generation of cyclopentenone prostaglandins after brain ischemia and their role in aggregation of ubiquitinated proteins in neurons. Neurotox Res. 2013; 24:191-204. [PubMed: 23355003]

63. Smith DH, Johnson VE, Stewart W. Chronic neuropathologies of single and repetitive TBI: substrates of dementia? Nat Rev Neurol. 2013; 9:211-21. [PubMed: 23458973]

64. Hutson CB, Lazo CR, Mortazavi F, Giza CC, Hovda D, Chesselet MF. Traumatic brain injury in adult rats causes progressive nigrostriatal dopaminergic cell loss and enhanced vulnerability to the pesticide paraquat. J Neurotrauma. 2011; 28:1783-801. [PubMed: 21644813]

65. Becker C, Jick SS, Meier CR. Risk of stroke in patients with idiopathic Parkinson disease. Parkinsonism Relat Disord. 2010; 16:31-5. [PubMed: 19640771]

66. Kondo M, Shibata T, Kumagai T, Osawa T, Shibata N, Kobayashi M, Sasaki S, Iwata M, Noguchi N, Uchida K. 15-Deoxy-Delta(12,14)-prostaglandin J(2): the endogenous electrophile that induces neuronal apoptosis. Methods in Molecular Biology. 2002; 99:7367-72.

67. Li Z, Melandri F, Berdo I, Jansen M, Hunter L, Wright S, Valbrun D, Figueiredo-Pereira ME. Delta12-Prostaglandin J2 inhibits the ubiquitin hydrolase UCH-L1 and elicits ubiquitin-protein 
aggregation without proteasome inhibition. Biochemical and Biophysical Research Communications. 2004; 319:1171-80. [PubMed: 15194490]

68. Ogburn KD, Figueiredo-Pereira ME. Cytoskeleton/endoplasmic reticulum collapse induced by prostaglandin $\mathrm{J} 2$ parallels centrosomal deposition of ubiquitinated protein aggregates. journal of biological chemistry. 2006; 281:23274-84. [PubMed: 16774923]

69. Wang Z, Aris VM, Ogburn KD, Soteropoulos P, Figueiredo-Pereira ME. Prostaglandin J2 alters pro-survival and pro-death gene expression patterns and $26 \mathrm{~S}$ proteasome assembly in human neuroblastoma cells. journal of biological chemistry. 2006; 281:21377-86. [PubMed: 16737963]

70. Koharudin LM, Liu H, Di MR, Kodali RB, Graham SH, Gronenborn AM. Cyclopentenone prostaglandin-induced unfolding and aggregation of the Parkinson disease-associated UCH-L1. Methods in Molecular Biology. 2010; 107:6835-40.

71. Pignatelli M, Sanchez-Rodriguez J, Santos A, Perez-Castillo A. 15-Deoxy-\{Delta $\}-12,14-$ prostaglandin $\mathrm{J} 2$ induces programmed cell death of breast cancer cells by a pleiotropic mechanism. Carcinogenesis. 2005; 26:81-92. [PubMed: 15485993]

72. Mullally JE, Moos PJ, Edes K, Fitzpatrick FA. Cyclopentenone prostaglandins of the J series inhibit the ubiquitin isopeptidase activity of the proteasome pathway. journal of biological chemistry. 2001; 276:30366-73. [PubMed: 11390388]

73. Cocca C, Dorado J, Calvo E, Lopez JA, Santos A, Perez-Castillo A. 15-Deoxi-Delta(12,14)prostaglandin $\mathrm{J} 2$ is a tubulin-binding agent that destabilizes microtubules and induces mitotic arrest. Biochemical Pharmacology. 2009; 78:1330-9. [PubMed: 19576185]

74. Stamatakis K, Sanchez-Gomez FJ, Perez-Sala D. Identification of novel protein targets for modification by 15-deoxy-Delta12,14-prostaglandin J2 in mesangial cells reveals multiple interactions with the cytoskeleton. J Am Soc Nephrol. 2006; 17:89-98. [PubMed: 16291835]

75. Kondo M, Oya-Ito T, Kumagai T, Osawa T, Uchida K. Cyclopentenone prostaglandins as potential inducers of intracellular oxidative stress. journal of biological chemistry. 2001; 276:12076-83. [PubMed: 11278531]

76. Martinez B, Perez-Castillo A, Santos A. The mitochondrial respiratory complex I is a target for 15deoxy-delta12,14-prostaglandin J2 action. J Lipid Res. 2005; 46:736-43. [PubMed: 15654126]

77. Zhu T, Gobeil F, Vazquez-Tello A, Leduc M, Rihakova L, Bossolasco M, Bkaily G, Peri K, Varma DR, Orvoine R, Chemtob S. Intracrine signaling through lipid mediators and their cognate nuclear G-protein-coupled receptors: a paradigm based on PGE2, PAF, and LPA1 receptors. Can J Physiol Pharmacol. 2006; 84:377-91. [PubMed: 16902584]

78. Hata AN, Breyer RM. Pharmacology and signaling of prostaglandin receptors: multiple roles in inflammation and immune modulation. Pharmacol Ther. 2004; 103:147-66. [PubMed: 15369681]

79. Monneret G, Li H, Vasilescu J, Rokach J, Powell WS. 15-Deoxy-delta 12,14-prostaglandins D2 and J2 are potent activators of human eosinophils. Journal of Immunology. 2002; 168:3563-9.

80. Pettipher R, Hansel TT, Armer R. Antagonism of the prostaglandin D2 receptors DP1 and CRTH2 as an approach to treat allergic diseases. Nat Rev Drug Discov. 2007; 6:313-25. [PubMed: 17396136]

81. Gilroy DW. Eicosanoids and the endogenous control of acute inflammatory resolution. Int $\mathbf{J}$ Biochem Cell Biol. 2010; 42:524-8. [PubMed: 20026423]

82. Paulitschke V, Gruber S, Hofstatter E, Haudek-Prinz V, Klepeisz P, Schicher N, Jonak C, Petzelbauer P, Pehamberger H, Gerner C, Kunstfeld R. Proteome analysis identified the PPARgamma ligand 15d-PGJ2 as a novel drug inhibiting melanoma progression and interfering with tumor-stroma interaction. PLoS ONE. 2012; 7:e46103. [PubMed: 23049949]

83. Qi L, Jacob A, Wang P, Wu R. Peroxisome proliferator activated receptor-gamma and traumatic brain injury. Int J Clin Exp Med. 2010; 3:283-92. [PubMed: 21072262]

84. Kapadia R, Yi JH, Vemuganti R. Mechanisms of anti-inflammatory and neuroprotective actions of PPAR-gamma agonists. Front Biosci. 2008; 13:1813-26. [PubMed: 17981670]

85. Kiaei M. Peroxisome Proliferator-Activated Receptor-gamma in Amyotrophic Lateral Sclerosis and Huntington's Disease. PPAR Res. 2008; 2008:418765. [PubMed: 18464922]

86. Kerr BJ, Girolami EI, Ghasemlou N, Jeong SY, David S. The protective effects of 15-deoxy-Delta$(12,14)$-prostaglandin J(2) in spinal cord injury. Glia. 2008; 56:436-48. [PubMed: 18205174] 
87. Straus DS, Glass CK. Cyclopentenone prostaglandins: new insights on biological activities and cellular targets. Medicinal Research Reviews. 2001; 21:185-210. [PubMed: 11301410]

88. Satoh T, Lipton SA. Redox regulation of neuronal survival mediated by electrophilic compounds. Trends in Neurosciences. 2007; 30:37-45. [PubMed: 17137643]

89. Higdon A, Diers AR, Oh JY, Landar A, Darley-Usmar VM. Cell signalling by reactive lipid species: new concepts and molecular mechanisms. Biochem J. 2012; 442:453-64. [PubMed: 22364280]

90. Vasil'ev YV, Tzeng SC, Huang L, Maier CS. Protein modifications by electrophilic lipoxidation products: adduct formation, chemical strategies and tandem mass spectrometry for their detection and identification. Mass Spectrom Rev. 2014; 33:157-82. [PubMed: 24818247]

91. Ceaser EK, Moellering DR, Shiva S, Ramachandran A, Landar A, Venkartraman A, Crawford J, Patel R, Dickinson DA, Ulasova E, Ji S, Darley-Usmar VM. Mechanisms of signal transduction mediated by oxidized lipids: the role of the electrophile-responsive proteome. Biochemical Society Transactions. 2004; 32:151-5. [PubMed: 14748737]

92. Diers AR, Higdon AN, Ricart KC, Johnson MS, Agarwal A, Kalyanaraman B, Landar A, rleyUsmar VM. Mitochondrial targeting of the electrophilic lipid 15-deoxy-Delta12,14-prostaglandin $\mathrm{J} 2$ increases apoptotic efficacy via redox cell signalling mechanisms. Biochemical Journal. 2010; 426:31-41. [PubMed: 19916962]

93. Marcone S, Fitzgerald DJ. Proteomic identification of the candidate target proteins of 15-deoxydelta12,14-prostaglandin J2. Proteomics. 2013; 13:2135-9. [PubMed: 23606334]

94. Yamamoto Y, Takase K, Kishino J, Fujita M, Okamura N, Sakaeda T, Fujimoto M, Yagami T. Proteomic identification of protein targets for 15-deoxy-Delta(12,14)-prostaglandin $\mathrm{J} 2$ in neuronal plasma membrane. PLoS ONE. 2011; 6:e17552. [PubMed: 21445266]

95. Oeste CL, Perez-Sala D. Modification of cysteine residues by cyclopentenone prostaglandins: interplay with redox regulation of protein function. Mass Spectrom Rev. 2014; 33:110-25. [PubMed: 23818260]

96. Harris SG, Padilla J, Koumas L, Ray D, Phipps RP. Prostaglandins as modulators of immunity. Trends Immunol. 2002; 23:144-50. [PubMed: 11864843]

97. Wall SB, Oh JY, Diers AR, Landar A. Oxidative modification of proteins: an emerging mechanism of cell signaling. Front Physiol. 2012; 3:369. [PubMed: 23049513]

98. Mrak RE, Landreth GE. PPARgamma, neuroinflammation, and disease. J Neuroinflammation. 2004; 1:5. [PubMed: 15285797]

99. Giri S, Rattan R, Singh AK, Singh I. The 15-deoxy-delta12,14-prostaglandin J2 inhibits the inflammatory response in primary rat astrocytes via down-regulating multiple steps in phosphatidylinositol 3-kinase-Akt-NF-kappaB-p300 pathway independent of peroxisome proliferator-activated receptor gamma. J Immunol. 2004; 173:5196-208. [PubMed: 15470065]

100. Eucker J, Bangeroth K, Zavrski I, Krebbel H, Zang C, Heider U, Jakob C, Elstner E, Possinger K, Sezer O. Ligands of peroxisome proliferator-activated receptor gamma induce apoptosis in multiple myeloma. Anti-cancer Drugs. 2004; 15:955-60. [PubMed: 15514564]

101. Meade EA, McIntyre TM, Zimmerman GA, Prescott SM. Peroxisome proliferators enhance cyclooxygenase-2 expression in epithelial cells. J Biol Chem. 1999; 274:8328-34. [PubMed: 10075740]

102. Zhang X, Wang JM, Gong WH, Mukaida N, Young HA. Differential regulation of chemokine gene expression by 15-deoxy-delta 12,14 prostaglandin J2. J Immunol. 2001; 166:7104-11. [PubMed: 11390455]

103. Shivers KY, Nikolopoulou A, Machlovi SI, Vallabhajosula S, Figueiredo-Pereira ME. PACAP27 prevents Parkinson-like neuronal loss and motor deficits but not microglia activation induced by prostaglandin J2. biochimica et biophysica acta. 2014; 1842:1707-19. [PubMed: 24970746]

104. Pierre SR, Lemmens MA, Figueiredo-Pereira ME. Subchronic infusion of the product of inflammation prostaglandin J2 models sporadic Parkinson's disease in mice. J Neuroinflammation. 2009; 6:18. [PubMed: 19630993]

105. Scher JU, Pillinger MH. The anti-inflammatory effects of prostaglandins. J Investig Med. 2009; 57:703-8. 
106. Uchida K, Shibata T. 15-Deoxy-Delta(12,14)-prostaglandin J2: an electrophilic trigger of cellular responses. Chemical Research In Toxicology. 2008; 21:138-44. [PubMed: 18052108]

107. Nakata S, Yoshida T, Shiraishi T, Horinaka M, Kouhara J, Wakada M, Sakai T. 15-DeoxyDelta12,14-prostaglandin J(2) induces death receptor 5 expression through mRNA stabilization independently of PPARgamma and potentiates TRAIL-induced apoptosis. Mol Cancer Ther. 2006; 5:1827-35. [PubMed: 16891469]

108. Su RY, Chi KH, Huang DY, Tai MH, Lin WW. 15-deoxy-Delta12,14-prostaglandin J2 upregulates death receptor 5 gene expression in HCT116 cells: involvement of reactive oxygen species and C/EBP homologous transcription factor gene transcription. Mol Cancer Ther. 2008; 7:3429-40. [PubMed: 18852146]

109. Metcalfe MJ, Huang Q, Figueiredo-Pereira ME. Coordination between proteasome impairment and caspase activation leading to TAU pathology: neuroprotection by cAMP. Cell Death Dis. 2012; 3:e326. [PubMed: 22717581]

110. Oliva JL, Perez-Sala D, Castrillo A, Martinez N, Canada FJ, Bosca L, Rojas JM. The cyclopentenone 15-deoxy-delta 12,14-prostaglandin J2 binds to and activates H-Ras. Proc Natl Acad Sci USA. 2003; 100:4772-7. [PubMed: 12684535]

111. Servidei T, Morosetti R, Ferlini C, Cusano G, Scambia G, Mastrangelo R, Koeffler HP. The cellular response to PPARgamma ligands is related to the phenotype of neuroblastoma cell lines. Oncology Research. 2004; 14:345-54. [PubMed: 15301425]

112. Wilmer WA, Dixon C, Lu L, Hilbelink T, Rovin BH. A cyclopentenone prostaglandin activates mesangial MAP kinase independently of PPARgamma. Biochem Biophys Res Commun. 2001; 281:57-62. [PubMed: 11178960]

113. Li Z, Jansen M, Ogburn K, Salvatierra L, Hunter L, Mathew S, Figueiredo-Pereira ME. Neurotoxic prostaglandin $\mathrm{J} 2$ enhances cyclooxygenase-2 expression in neuronal cells through the p38MAPK pathway: a death wish? J Neurosci Res. 2004; 78:824-36. [PubMed: 15523637]

114. Itoh K, Mochizuki M, Ishii Y, Ishii T, Shibata T, Kawamoto Y, Kelly V, Sekizawa K, Uchida K, Yamamoto M. Transcription factor Nrf2 regulates inflammation by mediating the effect of 15deoxy-Delta(12,14)-prostaglandin j(2). Mol Cell Biol. 2004; 24:36-45. [PubMed: 14673141]

115. Kaspar JW, Niture SK, Jaiswal AK. Nrf2:INrf2 (Keap1) signaling in oxidative stress. Free Radical Biology and Medicine. 2009; 47:1304-9. [PubMed: 19666107]

116. Haskew-Layton RE, Payappilly JB, Xu H, Bennett SA, Ratan RR. 15-Deoxy-Delta12,14prostaglandin J2 (15d-PGJ2) protects neurons from oxidative death via an Nrf2 astrocyte-specific mechanism independent of PPARgamma. Journal of Neurochemistry. 2013; 124:536-47. [PubMed: 23199167]

117. Rossi A, Kapahi P, Natoli G, Takahashi T, Chen Y, Karin M, Santoro MG. Anti-inflammatory cyclopentenone prostaglandins are direct inhibitors of IkappaB kinase. Nature. 2000; 403:103-8. [PubMed: 10638762]

118. Straus DS, Pascual G, Li M, Welch JS, Ricote M, Hsiang CH, Sengchanthalangsy LL, Ghosh G, Glass CK. 15-deoxy-delta 12,14-prostaglandin J2 inhibits multiple steps in the NF-kappa B signaling pathway. Methods in Molecular Biology. 2000; 97:4844-9.

119. Aoki T, Narumiya S. Prostaglandins and chronic inflammation. Trends in Pharmacological Sciences. 2012; 33:304-11. [PubMed: 22464140]

120. Kim EH, Na HK, Kim DH, Park SA, Kim HN, Song NY, Surh YJ. 15-Deoxy-Delta12,14prostaglandin J2 induces COX-2 expression through Akt-driven AP-1 activation in human breast cancer cells: a potential role of ROS. Carcinogenesis. 2008; 29:688-95. [PubMed: 18192694]

121. Kitz K, Windischhofer W, Leis HJ, Huber E, Kollroser M, Malle E. 15-Deoxy-Delta12,14prostaglandin $\mathrm{J} 2$ induces Cox-2 expression in human osteosarcoma cells through MAPK and EGFR activation involving reactive oxygen species. Free Radical Biology and Medicine. 2011; 50:854-65. [PubMed: 21236332]

122. Higdon AN, Landar A, Barnes S, Darley-Usmar VM. The electrophile responsive proteome: integrating proteomics and lipidomics with cellular function. Antioxid Redox Signal. 2012; 17:1580-9. [PubMed: 22352679]

123. Espinosa-Oliva AM, de Pablos RM, Herrera AJ. Intracranial injection of LPS in rat as animal model of neuroinflammation. Methods Mol Biol. 2013; 1041:295-305. [PubMed: 23813388] 
124. Czerniawski J, Miyashita T, Lewandowski G, Guzowski JF. Systemic lipopolysaccharide administration impairs retrieval of context-object discrimination, but not spatial, memory: Evidence for selective disruption of specific hippocampus-dependent memory functions during acute neuroinflammation. Brain, Behavior, and Immunity. 2015; 44:159-66.

125. Qin L, Wu X, Block ML, Liu Y, Breese GR, Hong JS, Knapp DJ, Crews FT. Systemic LPS causes chronic neuroinflammation and progressive neurodegeneration. Glia. 2007; 55:453-62. [PubMed: 17203472]

126. Nazem A, Sankowski R, Bacher M, Al-Abed Y. Rodent models of neuroinflammation for Alzheimer's disease. J Neuroinflammation. 2015; 12:74. [PubMed: 25890375]

127. Liu M, Bing G. Lipopolysaccharide animal models for Parkinson's disease. Parkinsons Dis. 2011; 2011:327089. [PubMed: 21603177]

128. Lee JW, Lee YK, Yuk DY, Choi DY, Ban SB, Oh KW, Hong JT. Neuro-inflammation induced by lipopolysaccharide causes cognitive impairment through enhancement of beta-amyloid generation. J Neuroinflammation. 2008; 5:37. [PubMed: 18759972]

129. Pintado C, Gavilan MP, Gavilan E, Garcia-Cuervo L, Gutierrez A, Vitorica J, Castano A, Rios RM, Ruano D. Lipopolysaccharide-induced neuroinflammation leads to the accumulation of ubiquitinated proteins and increases susceptibility to neurodegeneration induced by proteasome inhibition in rat hippocampus. J Neuroinflammation. 2012; 9:87. [PubMed: 22559833]

130. Zhang J, Stanton DM, Nguyen XV, Liu M, Zhang Z, Gash D, Bing G. Intrapallidal lipopolysaccharide injection increases iron and ferritin levels in glia of the rat substantia nigra and induces locomotor deficits. Neuroscience. 2005; 135:829-38. [PubMed: 16165292]

131. Iravani MM, Leung CC, Sadeghian M, Haddon CO, Rose S, Jenner P. The acute and the longterm effects of nigral lipopolysaccharide administration on dopaminergic dysfunction and glial cell activation. European Journal of Neuroscience. 2005; 22:317-30. [PubMed: 16045485]

132. Iannaccone PM, Jacob HJ. Rats! Dis. Model Mech. 2009; 2:206-10.

133. Blesa J, Phani S, Jackson-Lewis V, Przedborski S. Classic and new animal models of Parkinson's disease. J Biomed Biotechnol. 2012; 2012:845618. [PubMed: 22536024]

134. Moody TW, Ito T, Osefo N, Jensen RT. VIP and PACAP: recent insights into their functions/ roles in physiology and disease from molecular and genetic studies. Curr Opin Endocrinol Diabetes Obes. 2011; 18:61-7. [PubMed: 21157320]

135. Joo KM, Chung YH, Kim MK, Nam RH, Lee BL, Lee KH, Cha CI. Distribution of vasoactive intestinal peptide and pituitary adenylate cyclase-activating polypeptide receptors (VPAC1, VPAC2, and PAC1 receptor) in the rat brain. J Comp Neurol. 2004; 476:388-413. [PubMed: 15282712]

136. Takei N, Skoglosa Y, Lindholm D. Neurotrophic and neuroprotective effects of pituitary adenylate cyclase-activating polypeptide (PACAP) on mesencephalic dopaminergic neurons. J Neurosci Res. 1998; 54:698-706. [PubMed: 9843161]

137. Huang H, Wang H, Figueiredo-Pereira ME. Regulating the Ubiquitin/Proteasome Pathway Via cAMP-signaling: Neuroprotective Potential. Cell Biochem Biophys. 2013; 67:55-66. [PubMed: 23686612]

138. Silveira MS, Linden R. Neuroprotection by cAMP: Another brick in the wall. Advances In Experimental Medicine and Biology. 2006; 557:164-76. [PubMed: 16955710]

139. Reglodi D, Kiss P, Lubics A, Tamas A. Review on the Protective Effects of PACAP in Models of Neurodegenerative Diseases In vitro and In vivo. Curr Pharm Des. 2011; 17:962-72. [PubMed: 21524257]

140. Lipton SA. Pathologically activated therapeutics for neuroprotection. Nat Rev Neurosci. 2007; 8:803-8. [PubMed: 17882256]

141. Satoh T, McKercher SR, Lipton SA. Reprint of: Nrf2/ARE-mediated antioxidant actions of proelectrophilic drugs. Free Radical Biology and Medicine. 2014; 66:45-57. [PubMed: 24262357]

142. Satoh T, Stalder R, McKercher SR, Williamson RE, Roth GP, Lipton SA. Nrf2 and HSF-1 Pathway Activation via Hydroquinone-Based Proelectrophilic Small Molecules is Regulated by Electrochemical Oxidation Potential. ASN Neuro. 2015; 7

143. Levonen AL, Dickinson DA, Moellering DR, Mulcahy RT, Forman HJ, Darley-Usmar VM. Biphasic effects of 15-deoxy-delta(12,14)-prostaglandin $\mathrm{J}(2)$ on glutathione induction and 
apoptosis in human endothelial cells. Arterioscler Thromb Vasc Biol. 2001; 21:1846-51. [PubMed: 11701476]

144. Katura T, Moriya T, Nakahata N. 15-Deoxy-delta 12,14-prostaglandin J2 biphasically regulates the proliferation of mouse hippocampal neural progenitor cells by modulating the redox state. Molecular Pharmacology. 2010; 77:601-11. [PubMed: 20086036]

145. Xiang Z, Lin T, Reeves SA. 15d-PGJ2 induces apoptosis of mouse oligodendrocyte precursor cells. J Neuroinflammation. 2007; 4:18. [PubMed: 17634127] 


\section{J2 PROSTAGLANDINS}
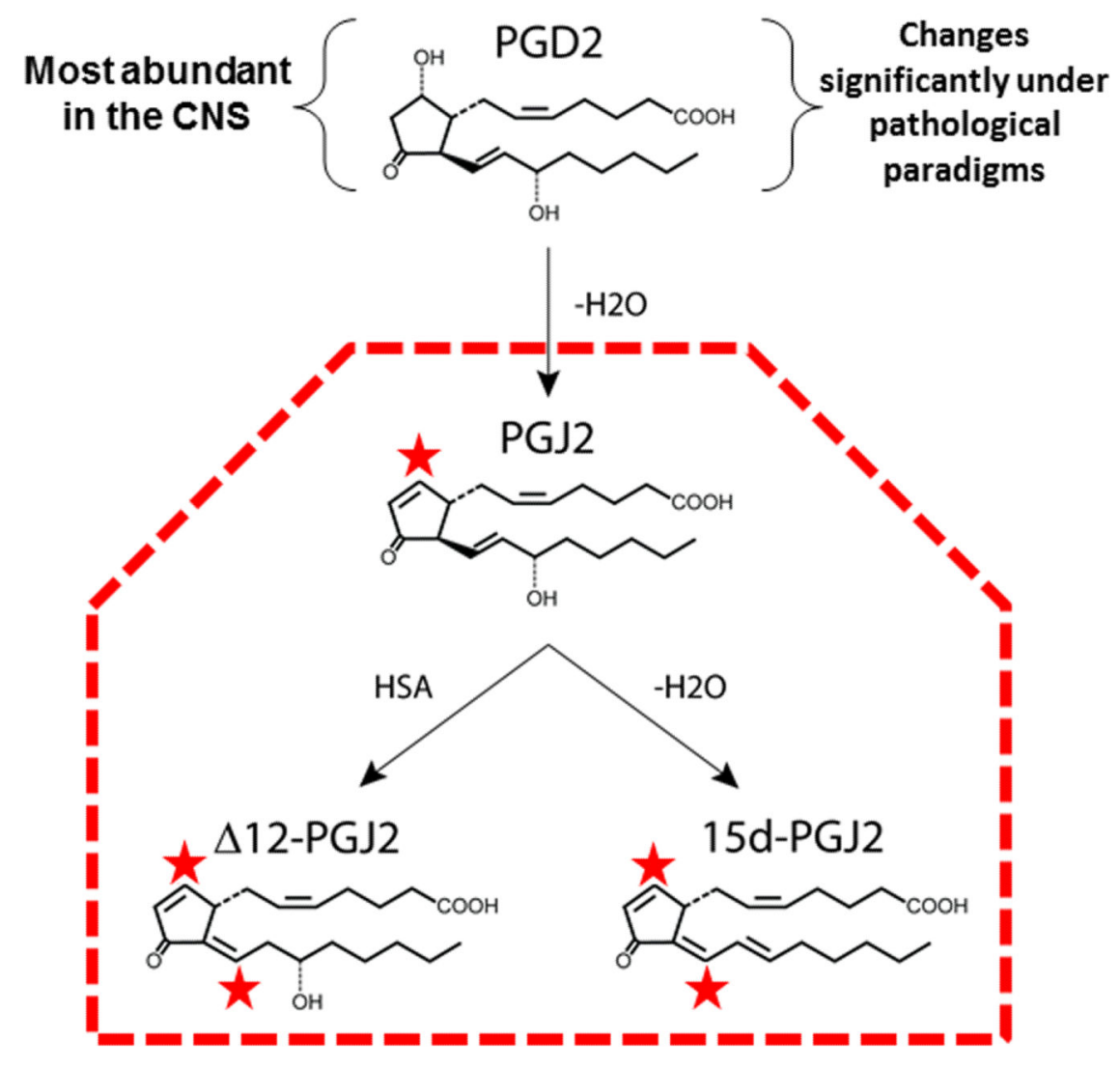

Figure 1.

Formation of PGJ2 and its metabolites. PGJ2 is a product of spontaneous dehydration ($\mathrm{H}_{2} \mathrm{O}$ ) of PGD2, which is the most abundant prostaglandin in the brain and the one that changes the most under pathological conditions. PGJ2 can be further metabolized into $\Delta 12$ and 15 d-PGJ 2 by reactions catalyzed by human serum albumin (HSA) or by dehydration ($\mathrm{H}_{2} \mathrm{O}$ ), respectively. In rodents, the in vivo concentration of free PGJ2 in the brain upon stroke and TBI increases to neurotoxic levels. Since PGJ2 binds covalently to proteins and GSH, its cellular and intracellular concentrations in the brain are predicted to be much higher than free PGJ2. The stars indicate highly reactive a,b-unsaturated carbonyl groups. 


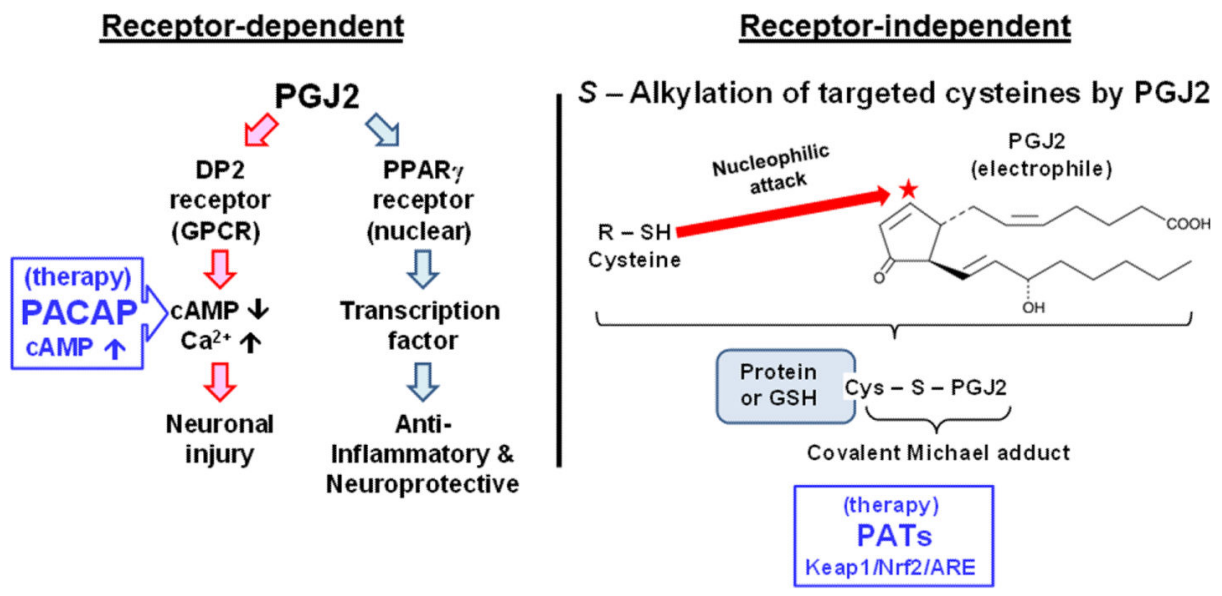

Figure 2.

Receptor-dependent and independent actions of PGJ2. Some of the PGJ2 effects are receptor mediated. The DP2 receptor, which is a G protein-coupled receptor (GPCR) for PGD2, is coupled to $\mathrm{G}_{i}$, thus decreasing cAMP levels and increasing intracellular calcium. DP2 activation is linked to neuronal injury. We established that the peptide PACAP, which binds to its PAC1R receptor and increases cAMP, prevents some of the adverse effects of PGJ2. The nuclear receptor PPAR $\gamma$ is a transcription factor. PPAR $\gamma$ activation is associated with anti-inflammatory and neuroprotective signaling. Moreover, unlike most prostaglandins, PGJ2 and its metabolites ( $\Delta 12-\mathrm{PGJ} 2$ and $15 \mathrm{~d}-\mathrm{PGJ} 2)$ have a cyclopentenone ring with reactive $\alpha, \beta$-unsaturated carbonyl groups (red star) that mediate their receptor-independent effects. Through $S$-alkylation, these groups form covalent Michael adducts with free sulfhydryls in cysteine residues in glutathione and cellular proteins. This covalent posttranslational modification by PGJ2 in the brain represents a novel pathologic change and could play a critical role in neurodegeneration in AD and PD. Pathologically activated therapeutics (PATs) are small molecules that become chemically activated at sites of tissue injury undergoing oxidative stress. These PATs are postulated to counteract the effects of electrophiles such as PGJ2, by activating the Keap1/Nrf2/ARE transcription pathway. Activation of the latter pathway induces the synthesis of endogenous antioxidant phase 2 enzymes that protect against oxidative and electrophilic stresses. 


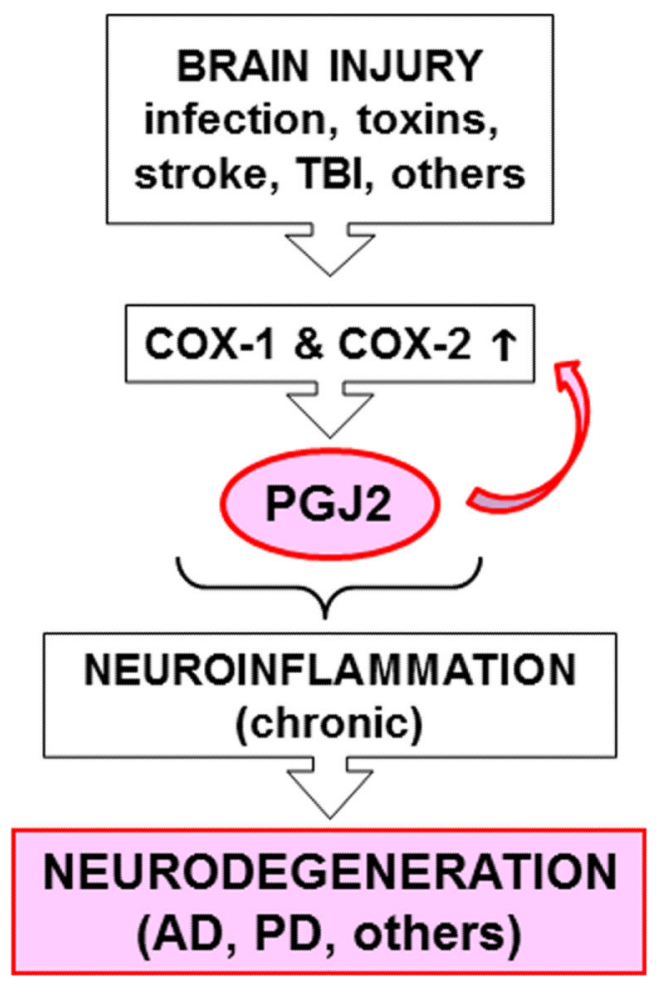

Figure 3.

PGJ2 is a potential factor in the transition from acute to chronic inflammation. Besides being mediators of acute inflammation, prostaglandins also function in the transition and maintenance of chronic inflammation, thus inducing long-lasting effects. Prostaglandins, such as PGJ2, accomplish this by amplifying cytokine signaling, upregulating COX-2, inducing chemokines, and recruiting inflammatory cells such as macrophages. Thus, therapeutically targeting prostaglandins such as PGJ2 has potential to prevent/block chronic neuroinflammation relevant to neurodegeneration in $\mathrm{AD}$ and PD. 